\title{
Annual and seasonal glaciological mass balance of Patsio Glacier, western Himalaya (India) from 2010 to 2017
}

\section{Article}

Cite this article: Angchuk T, Ramanathan $A$, Bahuguna IM, Mandal A, Soheb M, Singh VB, Mishra S, Vatsal S (2021). Annual and seasonal glaciological mass balance of Patsio Glacier, western Himalaya (India) from 2010 to 2017. Journal of Glaciology 67(266), 1137-1146. https://doi.org/10.1017/jog.2021.60

Received: 3 June 2020

Revised: 7 May 2021

Accepted: 10 May 2021

First published online: 16 June 2021

\section{Keywords:}

Glacier mass balance; Himalayan glaciers; winter mass balance

\section{Authors for correspondence:}

Thupstan Angchuk,

Email: thups001@gmail.com;

Alagappan Ramanathan, Email: alrjnu@gmail. com

\author{
Thupstan Angchuk ${ }^{1,2}$ (D), Alagappan Ramanathan ${ }^{1}$ (D) I. M. Bahuguna ${ }^{3}$ (D), \\ Arindan Mandal ${ }^{1}\left(\mathbb{D}\right.$, Mohd Soheb ${ }^{1}$ (D), Virendra Bahadur Singh ${ }^{4}$ (D), \\ Somdutta Mishra ${ }^{1}$ and Sarvagya Vatsal $^{1}$ (D)
}

${ }^{1}$ School of Environmental Sciences, Jawaharlal Nehru University, New Delhi 110067, India; ${ }^{2}$ Department of Geology, DST's Centre of Excellence, Sikkim University, Gangtok, Sikkim 737102, India; ${ }^{3}$ Space Applications Centre, Ahmedabad 380015, India and ${ }^{4}$ Department of Geology, University of Delhi, Delhi 110007, India

\begin{abstract}
Improving the knowledge on Himalayan glaciers mass balance is a key to understand the present and past annual atmospheric variations and future water availability in the region. Here, we present glaciological mass balance for Patsio Glacier, located in Himachal Pradesh (India), western Himalaya. Annual glacier-wide mass balance was measured for 7 consecutive years (2010/11 to 2016/17) and winter mass balance for 6 years (2011/12 to 2016/17). The cumulative mass balance over this period was $-2.35 \pm 0.37 \mathrm{~m}$ w.e. The corresponding mean mass balance was $-0.34 \mathrm{~m}$ w.e. $\mathrm{a}^{-1}$. The mean annual ablation gradient excluding the debris-covered area was $0.47 \mathrm{~m}$ w.e. $(100 \mathrm{~m})^{-1}$. The annual ablation over the debris-covered area is reduced by an average of $-1.0 \mathrm{~m}$ w.e. compared to the clean ice surface. Winter mass balance was consistently positive with a maximum of $1.34 \mathrm{~m}$ w.e. in $2014 / 15$ and a minimum of $0.88 \mathrm{~m}$ w.e. in 2011/12. Multiple regression analysis between annual mass balance versus annual and winter precipitation of the Lahaul-Spiti region shows a significant positive correlation. Our results highlight the importance of monitoring seasonal mass balance and consideration of non-climatic parameters (debris and aspect) while estimating the glacier-wide mass balance.
\end{abstract}

\section{Introduction}

Glaciers are freshwater reservoirs and store water in the form of snow and ice over different timescales. Mountain glaciers make a significant contribution to the current rate of sea-level rise (Dyurgerov and Meier, 1997; Gardner and others, 2013; Zemp and others, 2019). The glaciers are highly sensitive to the meteorological parameters; therefore, glaciers are visually and quantitatively, one of the most reliable indicators of climate change (Huss and Fischer, 2016).

The meltwater from the snow and glaciers of the Hindu-Kush Himalayan $(\mathrm{HKH})$ region is the main water resource for the downstream regions (Immerzeel and others, 2010). These water resources sustain millions of people socially as well as economically. The western Himalayan regions are highly dependent on the snow and glacier melt during the dry seasons (Armstrong and others, 2018; Pritchard, 2019). Therefore, understanding the changes of snow and glaciers and their impacts on the social and economic structure has become essential.

The Himalayan region comprises a large area with diverse terrain and distinct climate regimes, which has one of the largest concentrations of glaciers outside the Earth's polar region. Monitoring and understanding of the Himalayan glaciers have been improved in the recent past (Pratap and others, 2016; Azam and others, 2018). However, due to a large number of glaciers with distinct glacier responses, it has become necessary to investigate glacier changes across the Himalaya.

Glacier mass balance is determined by various methods such as glaciological (field-based), geodetic (field/remotely sensed) and glacier melt modelling (physical-based). However, to measure the glacier-wide annual mass balance, the glaciological method is the classical approach (Cuffey and Paterson, 2010). The monitoring of seasonal mass balance helps in assessing the accumulation and ablation processes at the glacier surface (Dyurgerov and Meier, 1999; Thibert and others, 2013). The estimation of winter $\left(B_{\mathrm{w}}\right)$ and summer mass balance $\left(B_{\mathrm{s}}\right)$ can closely relate to the inter-annual changes in the meteorological conditions (Cogley and others, 2011; Wagnon and others, 2013). However, most of the glaciological mass-balance studies in the Himalaya are focused on annual mass balance $\left(B_{\mathrm{a}}\right)$ (e.g. Dobhal and others, 2013; Sherpa and others, 2017; Acharya and others, 2018; Soheb and others, 2020).

Long-term observations of the glacier mass balance around the world show a negative trend between 1961 and 2016 (Zemp and others, 2019). Field-based measurements and remotely sensed studies show a negative mass balance all over the Himalayan region (Brun and others, 2017; Azam and others, 2018; Bolch and others, 2019) with an exception in the Karakoram region where glaciers are in a nearly balanced state (Bhambri and others, 2013; Bolch and others, 2017; Farinotti and others, 2020). However, the observed mass loss was heterogeneous across the Himalaya, with variation over regional to local scales (Brun and others, 2017; Shean 


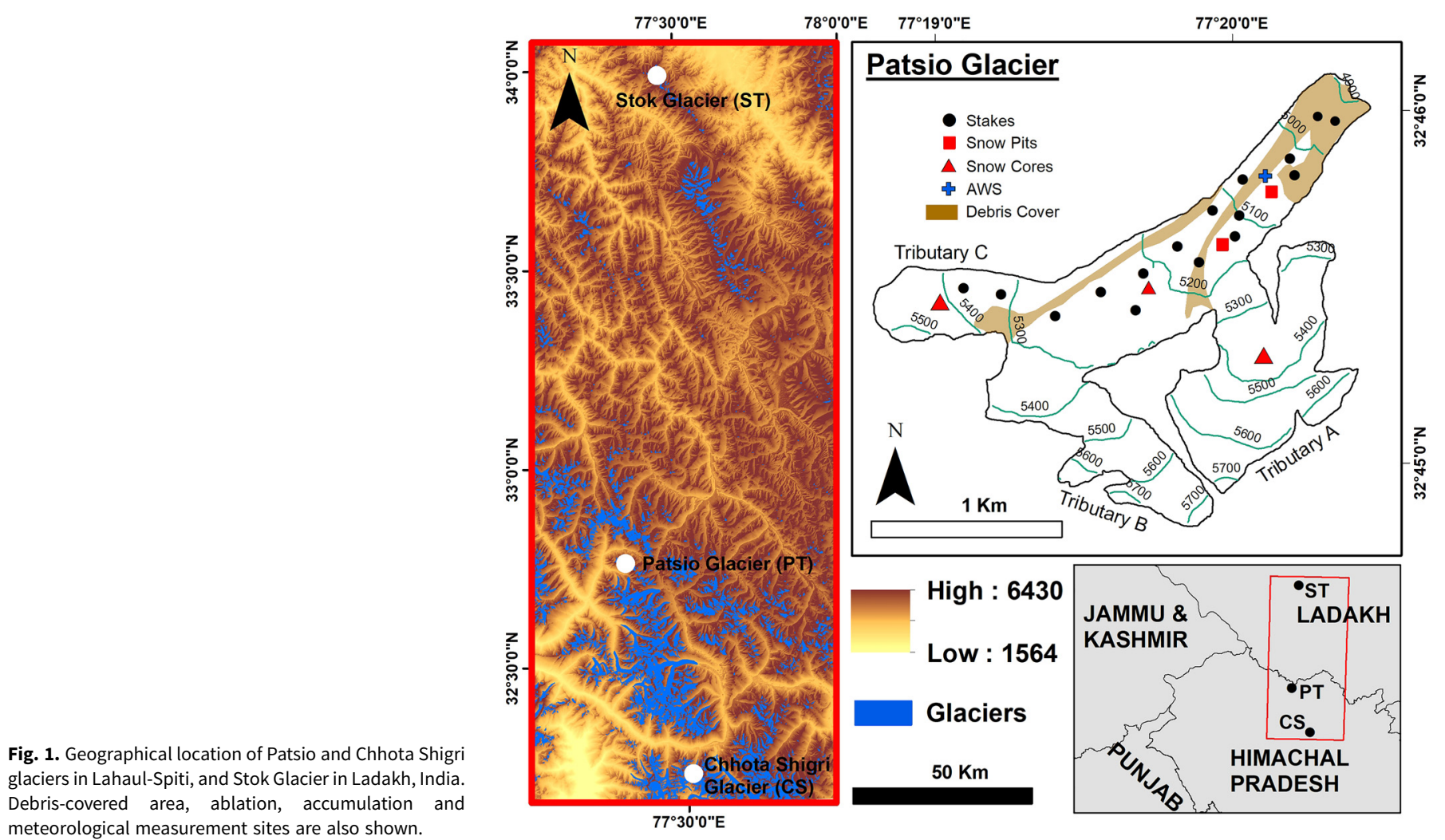

meteorological measurement sites are also shown.

and others, 2020). The glacier mass loss after 2000 for the HKH region shows a higher mass-loss rate in the western and eastern Himalaya $\left(-0.6 \mathrm{~m}\right.$ w.e. $\left.\mathrm{a}^{-1}\right)$ compared to central Himalaya $\left(-0.4 \mathrm{~m}\right.$ w.e. $\left.\mathrm{a}^{-1}\right)$ (Bolch and others, 2019). Maurer and others (2019) observed an increased mass loss in the past two decades with an exceptional increased rate (factor of 3 ) in the Lahaul-Spiti region. Some of the studies show that spatial variation in glacier mass balance in the high-mountain Asian region is dependent on the sensitivity of the regional climate (Wang and others, 2019) as well as on the glacier geomorphology (Brun and others, 2019). However, this spatially and temporally heterogeneous pattern of mass loss is not fully understood so far. Therefore, analysis of seasonal mass-balance components along with micro-climate could reveal the glacier characteristics and behaviours. Furthermore, it will help to understand the present state as well as the factors which govern the mass balance of the glaciers (Wagnon and others, 2013; Brun and others, 2017; Sakai and Fujita, 2017).

In this study, we investigated Patsio Glacier which is in the Bhaga basin of the Lahaul-Spiti region located near the Baralacha Pass of the Great Himalayan range. This study presents the field-based $B_{\mathrm{a}}$ and $B_{\mathrm{w}}$ for Patsio Glacier between 2010 and 2017. We also analysed the interrelationship between winter accumulation and $B_{\mathrm{a}}$. Furthermore, we studied the role of non-climatic parameters that govern the glacier-wide mass balance.

\section{Study area}

Patsio Glacier is a small valley-type glacier with an area of $2.25 \mathrm{~km}^{2}$, located with an altitude range of $4875-5718 \mathrm{~m}$ a.s.l. (Fig. 1). The glacier lies in the Lahaul-Spiti region of Himachal Pradesh, India. Lahaul-Spiti region falls in the monsoon-arid transition zone where the precipitation is influenced by Western Disturbances (WDs) in winter and Indian Summer Monsoon (ISM) in summer (Bookhagen and others, 2005). Patsio Glacier is fed by three tributaries. Two are located on the eastern flank (tributaries A and B) and one on the western flank (tributary C) of the glacier (Fig. 1). The orientation of the main glacier trunk is northeast (NE) in the ablation area. However, the orientations of tributaries $\mathrm{A}$ and $\mathrm{B}$ are almost towards northwest, and tributary $\mathrm{C}$ is oriented almost towards the east. Tributaries A and B cover the larger area $(\sim 45 \%$ of the total glacier area) in comparison with tributary C $(\sim 12 \%)$. The glacier has a wide valley of $\sim 2 \mathrm{~km}$ at higher altitudes and gets narrower to $<0.5 \mathrm{~km}$ with decreasing altitude. At the terminus, it is only $\sim 300-400 \mathrm{~m}$ wide, and the frontal part is vertically steep. The average slope of the glacier is $14^{\circ}$ (Kumar and others, 2018). At the lower altitude, the glacier is separated by a large-medial moraine (Fig. 1). Two medial moraines exist, one with a thin-small length located at the convergence of tributary $\mathrm{C}$ with the main glacier trunk, which later forms the part of the lateral moraine (Fig. 1). The main-medial moraine originates from $\sim 5270 \mathrm{~m}$ a.s.l. Further down, it covers a large area around the glacier terminus. The length of the main-medial moraine is $\sim 1.41 \mathrm{~km}$ and covers an area of $\sim 0.12 \mathrm{~km}^{2}$.

Meltwater from the glacier drains from two pro-glacial channels which coalesce and forms a single channel before joining the Bhaga river which is a tributary of the Chenab (Indus) river. The total glacier covered by debris including the mainmedial moraine is $\sim 0.29 \mathrm{~km}^{2}$, corresponding to $\sim 12 \%$ of the total glacier area. A small piece of dead ice with a length of $\sim 110 \mathrm{~m}$ was located $\sim 500 \mathrm{~m}$ below the terminus (Negi and others, 2013). A series of glacier depressions formed at the higher altitudes of the ablation zone between 5200 and $5250 \mathrm{~m}$ a.s.l. During the early ablation season, meltwater gets stored in these depressions, which act as a supra-glacial pond at the early ablation season and finally drains out at the peak ablation season through a series of meltwater channels. Table 1 and Figure 1 give the general, topographic and climate information of Patsio Glacier.

Preliminary studies mainly by remote sensing show a retreat of Patsio Glacier with an annual average frontal retreat of $\sim 22 \mathrm{~m} \mathrm{a}^{-1}$ between 1971 and 2011 (Negi and others, 2013). Geodetic analysis based on satellite images shows a thinning of $-0.31 \pm 0.13 \mathrm{~m} \mathrm{a}^{-1}$ between 2005 and 2013 (Kumar and others, 2018). Similarly, the average glacier velocity between 2014 and 2015 using the 
Table 1. Characteristics and general information of Patsio Glacier

\begin{tabular}{|c|c|}
\hline \multicolumn{2}{|l|}{ General information } \\
\hline Country, state & India, Himachal Pradesh \\
\hline District & Lahaul-Spiti \\
\hline Mountain range & $\begin{array}{l}\text { Great Himalayan range, western } \\
\text { Himalaya }\end{array}$ \\
\hline Drainage system & Chandra-Bhaga river (Indus) \\
\hline \multicolumn{2}{|l|}{ Glacier characteristics } \\
\hline Latitude & $32.73-32.77^{\circ} \mathrm{N}$ \\
\hline Longitude & $77.3-77.33^{\circ} \mathrm{E}$ \\
\hline Maximum altitude & $5718 \mathrm{~m}$ a.s.l. \\
\hline Snout position & 4875 m a.s.l. (2016) \\
\hline Total area & $2.25 \mathrm{~km}^{2}$ \\
\hline Debris-covered area & $\sim 0.29 \mathrm{~km}^{2}(\sim 12 \%)$ \\
\hline Glacier length & $\sim 2.6 \mathrm{~km}$ \\
\hline Mean orientation & North-East \\
\hline \multicolumn{2}{|c|}{ Long-term mass-balance information } \\
\hline Mean mass balance & $-0.34 \mathrm{~m}$ w.e. $\mathrm{a}^{-1}(2010-17)$ \\
\hline $\mathrm{ELA}_{0}$ & $\sim 5304 \mathrm{~m}$ a.s.l. \\
\hline $\mathrm{AAR}_{0}$ & $\sim 58 \%$ \\
\hline \multicolumn{2}{|l|}{ Meteorological information } \\
\hline $\begin{array}{l}\text { Mean annual temperature } \\
\text { (Patsio Glacier) }\end{array}$ & $-6.3^{\circ} \mathrm{C}$ (August 2015-September 2017 \\
\hline $\begin{array}{l}\text { Mean annual precipitation } \\
\text { (Lahaul-Spiti) }\end{array}$ & $585 \mathrm{~mm}\left(2010-17, \mathrm{IMD}^{\mathrm{a}}\right)$ \\
\hline
\end{tabular}

$\mathrm{ELA}_{0}$ and $\mathrm{AAR}_{0}$ are the calculated balanced budget ELA and AAR values, respectively. ${ }^{\mathrm{a}} \mathrm{IMD}=$ Indian Meteorological Department.

Landsat images was found to be $\sim 5 \mathrm{~m} \mathrm{a}^{-1}$ (Singh and others, 2018). Meteorological observations recorded for the period 1991-2010 at Snow and Avalanche Studies Establishment (SASE) Patsio station which is $7 \mathrm{~km}$ away from Patsio Glacier observed a decreasing trend in winter albedo and snowfall days, also increasing trend in winter temperature (Dimri and Dash, 2012; Negi and others, 2017).

\section{Method and data}

\subsection{Mass-balance methodology}

A series of field campaigns were conducted on Patsio Glacier since the year 2010, and glacier-wide mass balance was measured using the traditional glaciological method (Kaser and others, 2003; Cuffey and Paterson, 2010). The ablation was measured using bamboo stakes inserted into the ice surface up to $8-10 \mathrm{~m}$, distributed across the ablation zone (Fig. 1). In the accumulation zone, snow core, pits and depths were measured using manual auger drills (snow corer), digging manually and snow probe respectively (Fig. 1). Mass balance was calculated for each $50 \mathrm{~m}$ altitude band and the glacier-wide mass balance $(B)$ was calculated using Eqn (1) (Cuffey and Paterson, 2010):

$$
B=\sum b_{i}\left(\frac{s_{i}}{S}\right)
$$

where $b_{i}$ is the mass balance of the altitudinal range $i\left(\mathrm{~m}\right.$ w.e. $\left.\mathrm{a}^{-1}\right)$, of area $s_{i}$, and $S$ is the total area of the glacier. For each altitudinal range, $b_{i}$ is obtained from the corresponding stake readings or net accumulation measurements.

Conversion to w.e. was made by taking the density of ice as constant $900 \mathrm{~kg} \mathrm{~m}^{-3}$, and snow density from snow cores and pits measurements.

\subsubsection{Annual glacier-wide mass balance}

For calculation of $B_{\mathrm{a}}$, a hydrological year is defined from 1 October to 30 September of the following year for western Himalayan glaciers (Raina and others, 1977; Azam and others, 2016). Measurements of $B_{\mathrm{a}}$ were usually carried out at the end of September or the beginning of October based on the climatic conditions and human resources. In the year 2010, seven stakes were installed on Patsio Glacier surface between 4900 and 5200 $\mathrm{m}$ a.s.l. Later in 2012, ten more stakes were installed; seven of them were installed close $(\sim 10-30 \mathrm{~m})$ to the previous stakes and three at higher altitudes (5200-5300 $\mathrm{m}$ a.s.l.). In 2013, four stakes were installed on the debris zone of the glacier to get a better representation of the ablation zone. Furthermore, in 2016, four more stakes were installed at different locations, two at the upper zone ( $>5300 \mathrm{~m}$ a.s.l.) of tributary $\mathrm{C}$ and two at lower altitudes (Fig. 1). For the calculation of $B_{\mathrm{a}}$, minimum stake measurements were seven in 2010/11 and a maximum of 22 in 2013/14. Missing $b_{i}$ at the ablation zone was obtained by using a single linear fit to all available stake measurements. Annual point accumulation measurement was performed on tributary A, mostly $\sim 5375$ m a.s.l. (Fig. 1). However, in the years 2014, 2015 and 2017, snow core measurements were not possible due to heavy snowfall during fieldworks. Therefore, instead of snow core, snow pit and snow depths were measured (Table S1, Supplementary material). The missing snow density for annual accumulation measurement for the years 2014 and 2017 was assumed to be the mean of all available years. Azam and others (2016) have observed relatively less variability in snow density than that of snow depth at Chhota Shigri Glacier during the end of ablation season. Accumulation measured at $\sim 5375 \mathrm{~m}$ a.s.l. at the end of September or early October was considered as the net accumulation for higher altitudes. Measurement dates, the number of stakes and snow core/pit/probing sites with respective altitudes are presented in Table S1. Also, some of the challenges related to accumulation measurements are described in the Supplementary material under section 1. Equilibrium-line altitude (ELA) for each year was calculated based on annual point mass-balance measurements (excluding the debris-covered area and tributary C) between 5100 and $5400 \mathrm{~m}$ a.s.l. by applying a linear regression (Fig. 2). Accumulation-area ratio (AAR) was calculated using the ELA of the corresponding year following Mandal and others (2020). The annual ELA was calculated excluding the mass-balance values of tributary $\mathrm{C}$ due to the following reasons: (a) total area covered by tributary $\mathrm{C}$ is small $(\sim 12 \%)$ compared to the eastern $(\sim 45 \%)$ and (b) mass-balance measurements were limited to tributary $\mathrm{C}$.

\subsubsection{Winter/summer glacier-wide mass balance}

Avoiding the harsh climate and accessibility, which are the main hindrances of field observation in the Himalayan region, $B_{\mathrm{w}}$ measurements were carried out in late May or early June for the period 2012-17. For $B_{\mathrm{w}}$, snow core was measured at higher altitudes (5200-5400 m a.s.l.) and snow pit and depths at lower altitudes (4900-5200 m a.s.l.). At least one core/pit was measured throughout the study period. Also, from 2013 onwards an additional snow core was measured at a lower altitude ( $5220 \mathrm{~m}$ a.s.l.). In 2017, three snow cores were measured to check the distribution and accuracy of the data (Fig. 1). Detailed information is provided in the Supplementary material (Table S1). A minimum of eight (2015) and a maximum of 28 (2017) snow depth measurements were carried out throughout the study period (Table S1). Snow depths were measured manually with the help of a snow probe which was inserted inside the snowpack until it contacted the glacier surface. The point snow depth measurements were obtained by averaging three to six individual measurements almost within a radius of $\sim 5-10 \mathrm{~m}$. Snow density was measured by digging a snow pit and extracting snow cores (Cogley and others, 2011) (Fig. S1b). An averaged density was then used to convert snow depth readings into mass estimates (Kaser and others, 2003).

The summer glacier-wide mass balance $\left(B_{\mathrm{s}}\right)$ was obtained after subtracting the winter mass balance $\left(B_{\mathrm{w}}\right)$ from the annual mass balance $\left(B_{\mathrm{a}}\right)$. 

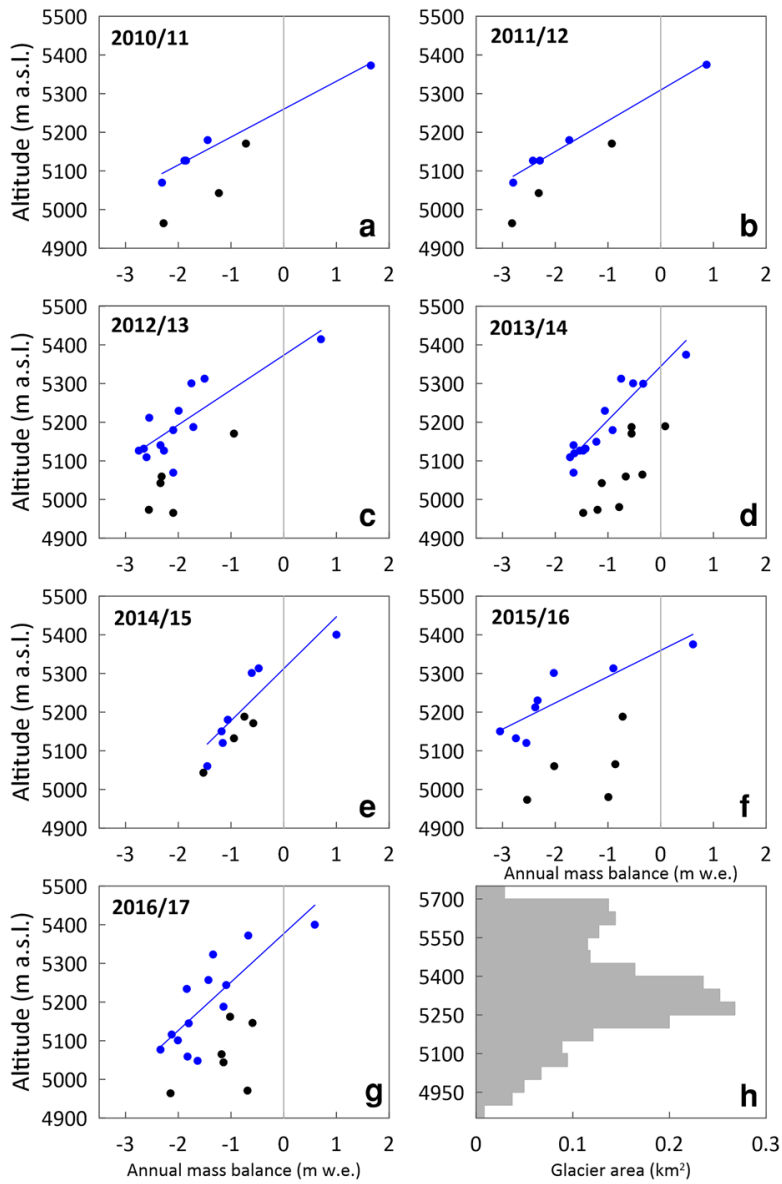

Fig. 2. Annual point mass balance (dots; panels a-g) as a function of altitude derived from field measurements (stakes, snow cores or pits) on Patsio Glacier between 2010 and 2017. Black dots represent the stakes over the debris/shadow area. Linear regression lines between 5100 and $5400 \mathrm{~m}$ a.s.l (excluding debris-covered area and tributary C) were used to compute the ELA. Hypsometry ( $50 \mathrm{~m}$ altitude bands) of Patsio Glacier is also shown (h).

\subsection{Other datasets}

We measured the stake locations with the help of a handheld GPS device (Garmin 76CSx) during most field campaigns. In 2016 and 2017, we performed the differential GPS (DGPS) survey (Leica Viva GS14) on the glacier surface using a kinematic mode relative to a fixed reference point $\left(32.77^{\circ} \mathrm{N}, 77.34^{\circ} \mathrm{E} ; 4848 \mathrm{~m}\right.$ a.s.l. $)$ just below the snout on a firm rock.

Debris thickness was measured in 2014 at two different horizontal profiles at $\sim 4900$ and $\sim 5000 \mathrm{~m}$ a.s.l. excluding the big boulders (Fig. S2). We measured debris thickness at nine different sites by manually digging through the debris to the glacier ice surface. The height of the debris was measured with the help of a measuring tape. However, the measurement sites were randomly selected in a horizontal line keeping the minimum and the maximum distances of 3 to $10 \mathrm{~m}$, respectively.

The glacier boundary was manually digitised with the help of Landsat 8 image (30 m resolution, acquired on 30 August 2015) downloaded from USGS (http://earthexplorer.usgs.gov) and a PlanetScope satellite image $(3 \mathrm{~m}$ resolution; acquired on 1 September 2018) (Planet Labs; https://www.planet.com). Glacier topography and altitude bands are obtained from Shuttle Radar Topography Mission (SRTM) data (USGS). Monthly precipitation data for Lahaul-Spiti district were obtained from IMD, Shimla (http://weathershimla.nic.in/). The precipitation data are the arithmetic mean of precipitations observed from stations in Lahaul-Spiti district. Additional air temperature data were used from the automatic weather station (AWS) (4863 m a.s.l.) located at Chhota Shigri Glacier ( $\sim 55 \mathrm{~km}$ away) (Mandal and others, 2020). More information is provided in the Supplementary material (see Sections 1 and 2).

\subsection{Uncertainty analysis}

The various error sources are associated with glaciological massbalance measurements, such as (1) point ablation and accumulation measurements and (2) interpolation and extrapolation of point measurements to the respective altitudinal bands (Thibert and others, 2008; Sold and others, 2016). Uncertainty related to point ablation measurements is generally comes from stake height determination and representation of the stakes for the particular altitudinal band. Our point annual ablation measurements at similar location and altitude excluding the debris-covered area show a $B_{\mathrm{a}}$ difference of 0.01-0.17 $\mathrm{m}$ w.e. Therefore, we considered this as the stake representative error $\left(\sigma_{\text {stake }}\right)$ and estimated the ablation error $\left(\sigma_{\mathrm{abb}}\right)$. In the accumulation zone, one of the main possible errors is the contribution of avalanches from the steep vertical sidewalls especially in the Himalayan glaciers (Laha and others, 2017). Patsio Glacier has minimum snow/ice-free headwalls, and the winter accumulation measurements show low spatial variability at higher altitudes (5200-5400 m a.s.l.; Fig. 5). Also, errors in accumulation measurements could be due to snow depth and density measurements. To assess the uncertainty in accumulation measurements, we followed the method adopted by Kenzhebaev and others $(2017)\left(\sigma_{\text {acc }}\right)$ : $(1)$ by assuming a linear increase in accumulation at higher altitudes, (2) constant measured accumulation values for accumulation zone and (3) inverse gradient in the highest two altitude bands. For a linear increase in accumulation, we used the accumulation gradient of $0.22 \mathrm{~m}$ w.e. $(100 \mathrm{~m})^{-1}$ measured at Chhota Shigri Glacier between 2002 and 2014 (Azam and others, 2016). Finally, the uncertainty in accumulation measurements $\left(\sigma_{\mathrm{acc}}\right)$ was obtained after taking the mean of standard deviation (SD) from all three approaches. Overall, mean annual glacier-wide mass-balance uncertainty $\left(\sigma_{\mathrm{Ba}}\right.$; Eqn (2)) obtained after considering all the measurement errors is found to be $\pm 0.37 \mathrm{~m}$ w.e. $\mathrm{a}^{-1}$. The expression for $\sigma_{\mathrm{Ba}}$ is as follows:

$$
\sigma_{\mathrm{Ba}}=\sqrt{\sigma_{\mathrm{abb}}^{2}+\sigma_{\mathrm{acc}}^{2}}
$$

Uncertainty analysis for glacier-wide $B_{\mathrm{w}}\left(\sigma_{\mathrm{Ba}}\right)$ was performed based on density and snow depth variations following Thibert and others (2008). The uncertainty obtained for $B_{\mathrm{w}}$ measurement was $\pm 0.21 \mathrm{~m}$ w.e. $\mathrm{a}^{-1}$. Uncertainty of the individual Himalayan glaciers using the glaciological method varies between \pm 0.27 and $\pm 0.53 \mathrm{~m}$ w.e. (e.g. Azam and others, 2012; Wagnon and others, 2013; Acharya and others, 2018; Sunako and others, 2019; Soheb and others, 2020) which is in agreement with our estimate.

\section{Results}

\subsection{Annual point mass-balance profile}

The annual point mass balance as a function of altitude for seven hydrological years (2010/11 to 2016/17) is presented in Figures $2 \mathrm{a}-\mathrm{g}$. The hypsometry (50 $\mathrm{m}$ bands) of Patsio Glacier is shown in Figure 2h. Annual point mass-balance measurements show that glacier surface conditions play an important role in annual ablation. The debris-covered area experienced ablation with an annual average value varying from -2.17 to $-0.72 \mathrm{~m}$ w.e. The horizontal profile measurement of debris thickness at $\sim 4900$ and $\sim 5000 \mathrm{~m}$ a.s.l. varies from 1 to $\sim 13 \mathrm{~cm}$ (Fig. S2). However, the spatial distribution of the debris thickness on the glacier 
Table 2. $B_{\mathrm{a}}, B_{\mathrm{w}}$ (m w.e.), ELA (m a.s.l.), AAR (\%) and $\mathrm{db} / \mathrm{dz}\left(\mathrm{m}\right.$ w.e. $\left.(100 \mathrm{~m})^{-1}\right)$ for Patsio Glacier between 2010 and 2017

\begin{tabular}{|c|c|c|c|c|c|c|c|c|c|c|c|}
\hline & $2010 / 11$ & $2011 / 12$ & $2012 / 13$ & $2013 / 14$ & $2014 / 15$ & $2015 / 16$ & $2016 / 17$ & Mean & SD & Max. & Min. \\
\hline$B_{\mathrm{a}}$ (m w.e.) & 0.08 & -0.51 & -0.61 & -0.25 & 0.07 & -0.68 & -0.45 & -0.34 & 0.32 & 0.08 & -0.68 \\
\hline $\mathrm{d} b / \mathrm{d} z_{\mathrm{abl}}$ & $0.44^{\mathrm{a}}$ & $0.46^{\mathrm{a}}$ & 0.37 & 0.59 & 0.34 & 0.67 & 0.41 & 0.47 & 0.12 & 0.67 & 0.34 \\
\hline ELA (m a.s.l.) & 5289 & 5350 & 5366 & 5330 & 5302 & 5354 & 5348 & 5334 & 28.03 & 5366 & 5289 \\
\hline AAR (\%) & 61 & 47 & 44 & 54 & 59 & 46 & 49 & 51 & 06 & 61 & 44 \\
\hline$B_{\mathrm{w}}$ (m w.e.) & & 0.88 & 1.07 & 1.28 & 1.34 & 0.90 & 1.16 & 1.11 & 0.19 & 1.34 & 0.88 \\
\hline $\mathrm{d} b / \mathrm{d} z B_{\mathrm{w}}$ & & 0.13 & 0.23 & 0.12 & 0.14 & 0.26 & 0.36 & 0.21 & 0.09 & 0.36 & 0.12 \\
\hline$B_{\mathrm{w}}$ OK (m w.e.) & & 0.84 & 1.00 & 1.21 & 1.28 & 0.88 & 1.07 & 1.05 & 0.18 & 1.28 & 0.84 \\
\hline
\end{tabular}

$\mathrm{d} b / \mathrm{d} z_{\mathrm{ab}}$ and $\mathrm{d} b / \mathrm{d} z B_{\mathrm{w}}$ stand for mass-balance gradient for ablation zone (5100-5350 m a.s.l.; debris-free area) and winter mass balance (4900-5400 $\mathrm{m}$ a.s.l.). Mean, SD, maximum (Max.) and minimum (Min.) are also displayed for every variable. $B_{\mathrm{w}}$ OK is winter mass balance calculated using ordinary kriging (spherical).

${ }^{\mathrm{a}} \mathrm{d} b / \mathrm{d} z_{\mathrm{abl}}$ was calculated based on all the available stakes $(4950-5200)$

surface varies vertically as well as horizontally. Debris thickness around the stake located at $4980 \mathrm{~m}$ a.s.l. was higher $(\sim 20 \mathrm{~cm})$ and has observed less ablation compared to the stake installed at $4970 \mathrm{~m}$ a.s.l. $(<8 \mathrm{~cm}$; Fig. S3). The mean ablation difference between the two stakes installed at $\sim 4980$ and $4970 \mathrm{~m}$ a.s.l was $\sim-1.25 \mathrm{~m}$ w.e. mainly due to the difference in debris thickness. Accumulation measured at $\sim 5375 \mathrm{~m}$ a.s.l. was lowest in $2013 / 14$ (0.48 m w.e.) and highest in 2010/11 (1.65 m w.e.) (Fig. 2).

\subsection{Annual and winter vertical mass-balance gradients $(\mathrm{db} / \mathrm{dz})$}

Vertical ablation gradient $\left(\mathrm{d} b / \mathrm{d} z_{\mathrm{abl}}\right)$ was calculated between 5100 and $5350 \mathrm{~m}$ a.s.l. excluding the debris-covered area for each hydrological year (Fig. 2, Table 2). However, for the hydrological years 2010/11 and 2011/12, $\mathrm{d} b / \mathrm{d} z_{\mathrm{abl}}$ was calculated using all the available stake measurements due to the limited number of stakes. A minimum $\mathrm{d} b / \mathrm{d} z_{\text {abl }}$ of $0.34 \mathrm{~m}$ w.e. $(100 \mathrm{~m})^{-1}$ and a maximum of 0.67 m w.e. $(100 \mathrm{~m})^{-1}$ was observed in $2014 / 15$ and $2015 / 16$, respectively. Winter mass-balance gradient $\left(\mathrm{d} b / \mathrm{d} z B_{\mathrm{w}}\right)$ was obtained using the point snow depth, pit and core measurements between 4900 and $5400 \mathrm{~m}$ a.s.l. (Fig. 5, Table 2 ). $\mathrm{d} b / \mathrm{d} z B_{\mathrm{w}}$ was consistently low throughout the study period with an $\mathrm{SD}$ of $\pm 0.09 \mathrm{~m}$ w.e. $(100 \mathrm{~m})^{-1}$. The shallow $\mathrm{d} b / \mathrm{d} z B_{\mathrm{w}}$ indicates the low vertical spatial variability of snow on the glacier surface during the winter period.

\subsection{Annual and cumulative glacier-wide mass balance}

The $B_{\mathrm{a}}$ of Patsio Glacier for the period 2010-17 is presented in Table 2. Figure 3 shows the $B_{\mathrm{a}}, B_{\mathrm{w}}$ and cumulative mass balance. Interannual mass-balance variability was moderate with an SD of $\pm 0.32 \mathrm{~m}$ w.e. Mean and cumulative $B_{\mathrm{a}}$ was $-0.34 \mathrm{~m}$ w.e. and $-2.35 \mathrm{~m}$ w.e., respectively for the period $2010-2017$. Two slightly positive $B_{\mathrm{a}}$ years were observed in $2010 / 11\left(B_{\mathrm{a}}=0.08 \mathrm{~m}\right.$ w.e. $)$ and $2014 / 15$ ( $B_{\mathrm{a}}=0.07 \mathrm{~m}$ w.e.). For other years, $B_{\mathrm{a}}$ was negative, ranging from -0.68 to $-0.25 \mathrm{~m}$ w.e. in $2015 / 16$ and $2013 / 14$, respectively.

\subsection{ELA and $A A R$}

Calculated ELA and AAR of Patsio Glacier between 2010 and 2017 are given in Table 2. ELA and AAR are directly related to $B_{\mathrm{a}}$. Both ELA and AAR showed a positive correlation with $B_{\mathrm{a}}$ between 2010 and 2017 ( $r=0.97$ and 0.98 for ELA and AAR respectively; Fig. 4). Minimum ELA was $5289 \mathrm{~m}$ a.s.l. in $2010 / 11\left(B_{\mathrm{a}}=0.08 \mathrm{~m}\right.$ w.e. $)$ and maximum was $5366 \mathrm{~m}$ a.s.l. in $2012 / 13$ ( $B_{\mathrm{a}}=-0.61 \mathrm{~m}$ w.e. $)$.

\subsection{Winter mass balance $\left(\mathrm{B}_{w}\right)$}

The $B_{\mathrm{w}}$ was positive throughout the study period with a minimum of $0.88 \mathrm{~m}$ w.e. in $2011 / 12$ to a maximum of $1.34 \mathrm{~m}$ w.e. in $2014 / 15$ (Table 2 and Fig. 3). Mean $B_{\mathrm{w}}$ of Patsio Glacier is $1.11 \mathrm{~m}$ w.e. $\mathrm{a}^{-1}$ over $2011 / 12$ to $2016 / 17$ (6 years) with a cumulative $B_{\mathrm{w}}$ of $6.63 \mathrm{~m}$ w.e. Interannual variability of $B_{\mathrm{w}}$ was low with an SD of $\pm 0.19 \mathrm{~m}$

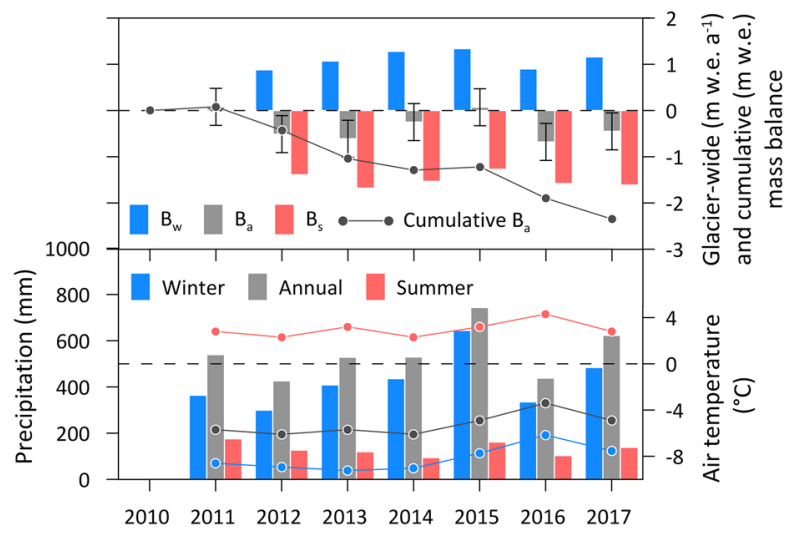

Fig. 3. Annual $\left(B_{\mathrm{a}}\right)$, winter $\left(B_{\mathrm{w}}\right)$, summer $\left(B_{\mathrm{s}}\right)$ and cumulative mass balance of Patsio Glacier between 2010 and 2017 are shown by grey, blue, pink histograms and grey line scatter for cumulative respectively. Annual, winter and summer precipitation of Lahaul-Spiti district of Himachal Pradesh are represented by grey, blue and pink histograms, respectively (obtained from IMD, Shimla; Section 3.2). The annual, winter and summer mean temperatures in grey, blue and pink line scatters respectively obtained from AWS installed at Chhota Shigri Glacier at $4863 \mathrm{~m}$ a.s.l.

w.e. $\mathrm{a}^{-1}$ compared to an SD of $B_{\mathrm{a}}: \pm 0.32 \mathrm{~m}$ w.e. $\mathrm{a}^{-1}$. The mean vertical gradient of winter mass balance $\left(\mathrm{d} b / \mathrm{d} z B_{\mathrm{w}}\right)$ was $0.21 \mathrm{~m}$ w.e. $(100 \mathrm{~m})^{-1}$ during the study period with a maximum value of $0.36 \mathrm{~m}$ w.e. $(100 \mathrm{~m})^{-1}$ in $2016 / 17$ and a minimum of $0.12 \mathrm{~m}$ w.e. $(100 \mathrm{~m})^{-1}$ in $2013 / 14$. The point $B_{\mathrm{w}}$ measurements are shown in Figure 5. The mean density of winter snowpack, an average of all available measurements at different altitudes, varying from 410 to $550 \mathrm{~kg} \mathrm{~m}^{-3}$, corresponding to a mean of $510 \mathrm{~kg}$ $\mathrm{m}^{-3}(n=16)$. At times, thin hard layers at various depths of snowpack were observed (Fig. S1b). The hard layers indicate the refreezing of the snow at various depths.

\section{Discussion}

\subsection{Role of debris cover and topography on the mass balance}

Annual point mass balance measured at the lower ablation zone (Fig. 2) was systematically reduced by $0.5-1.5 \mathrm{~m}$ w.e. $\mathrm{a}^{-1}$ compared to other parts of the ablation zone irrespective of their altitudes. This difference in surface melting is mainly due to the presence of debris at the lower parts of the glacier, which efficiently protects the glacier from melting (Wagnon and others, 2007; Banerjee and Shankar, 2013). The debris measurement at two different altitudes $\sim 4900$ and $\sim 5000 \mathrm{~m}$ a.s.l. show non-uniformity (Fig. S2). This difference in debris thickness has induced spatial variation in point mass balance at the debris-covered area (Fig. 2). Besides, the steep slope and surrounding narrow valley probably provide abundant debris onto the lower part of the glacier along with the shading effect, which acts as an insulator and reduced ice-melt (Wagnon and others, 2013). Stakes installed at $\sim 5175 \mathrm{~m}$ a.s.l. experienced 


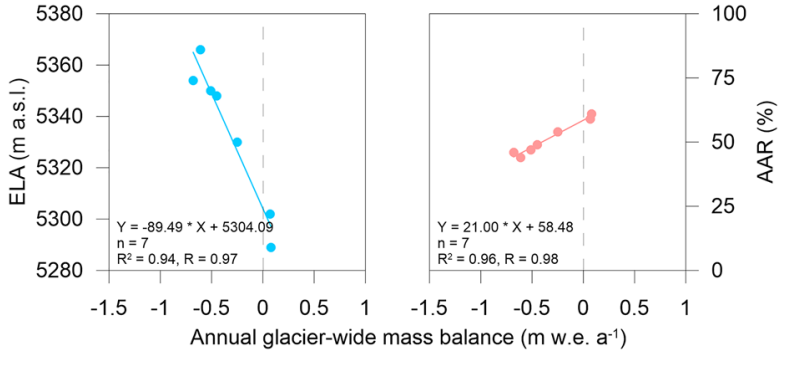

Fig. 4. ELA and AAR as a function of $B_{a}$ of Patsio Glacier.
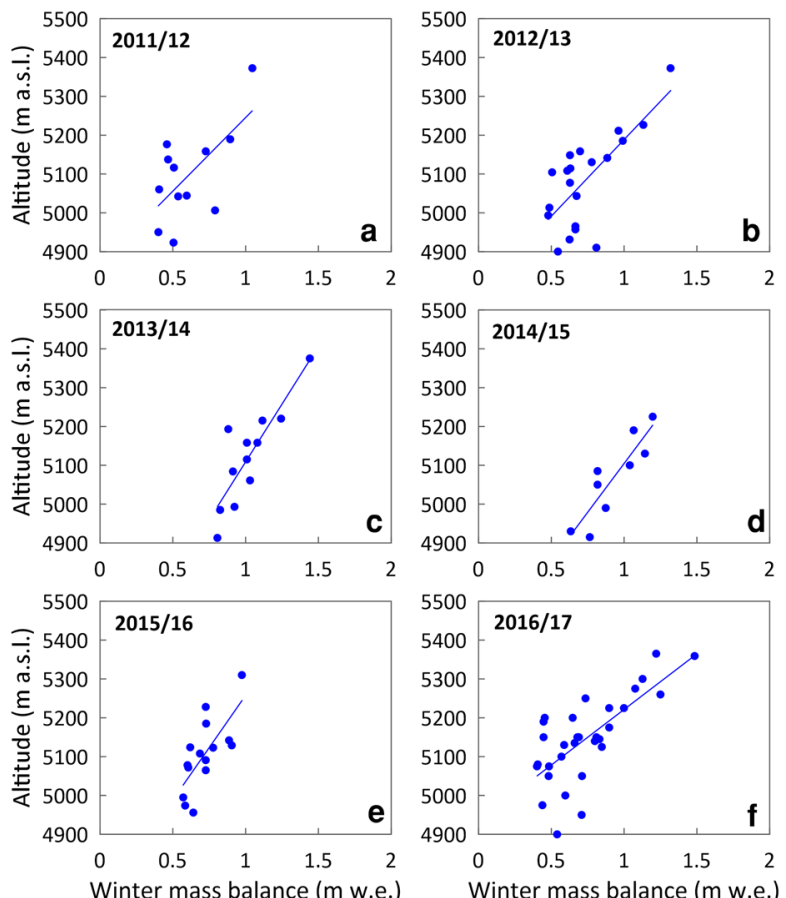

Fig. 5. Winter point mass balance (dots; panels a-f) as a function of altitude derived from field measurements (snow depths, pits and cores) on Patsio Glacier between 2012 and 2017.

less ablation ( $-0.74 \mathrm{~m}$ w.e.) compared to the stakes installed $\sim 5200 \mathrm{~m}$ a.s.l. $(-1.34 \mathrm{~m}$ w.e.). The glacier surface at $\sim 5175 \mathrm{~m}$ a.s.l. is also covered by debris, and oriented towards the NE, receiving less solar radiation. Also, snow depth measured during $B_{\mathrm{w}}$ measurements was higher around the stake located at $\sim 5175 \mathrm{~m}$ a.s.l. compared to stakes installed $\sim 5200 \mathrm{~m}$ a.s.l. In 2013/14, the annual point mass balance measured at $\sim 5175 \mathrm{~m}$ a.s.l. was slightly positive (Fig. 2d). Simultaneously, the point annual ablations measured for the year 2013/14 were low compared to other years (Fig. 2), which corresponds with the low summer temperature recorded at Chhota Shigri Glacier (Table S2).

In August 2016, two stakes were installed on tributary C ( $\sim 5360 \mathrm{~m}$ a.s.l.) of Patsio Glacier. In 2016/17, negative point mass balance was measured at those two stakes whereas positive point mass balance was measured (snow core) on tributary A at a similar altitude ( $\sim 5375 \mathrm{~m}$ a.s.l.). $B_{\mathrm{w}}$ measurements in $2016 / 17$ show similar snow depths on two different tributaries (A and C). The difference in $B_{\mathrm{w}}$ measurements at two different tributaries was only $0.25 \mathrm{~m}$ w.e., which suggest winter snow accumulations on tributaries $\mathrm{A}$ and $\mathrm{C}$ were almost uniform. Hence, the differences in the $B_{\mathrm{a}}$ measurements at the two different tributaries (A and $\mathrm{C}$ ) were mainly due to differences in summer mass balance which is the main ablation period in this region (Pratap and others, 2019; Mandal and others, 2020). The annual ablation measured at similar altitudes of the main glacier trunk showed uniform melting except at debris-covered areas because of the difference in debris thickness (Fig. S4). Therefore, the probable reason for such a difference in $B_{\mathrm{a}}$ at the two tributaries is their orientations. Tributary A is facing towards the north whereas tributary $\mathrm{C}$ is facing towards the east, receiving more solar radiation compared to tributary A. Higher solar radiation increases the surface temperature leading to higher melt. A similar difference was observed at Chhota Shigri Glacier (Wagnon and others, 2007; Mandal and others, 2020). Similarly, Schmidt and Nüsser (2017) stressed the importance of shading and radiation effects on glacier melting over the Trans-Himalayan region.

\section{$5.2 \mathrm{~B}_{a}$ and $\mathrm{B}_{w}$ variability}

$B_{\mathrm{a}}$ was mostly negative, except for 2010/11 and 2014/15 (Fig. 3). $B_{\mathrm{w}}$ shows a low spatiotemporal variation compared to $B_{\mathrm{a}}$ (Figs 5 , Fig. 2). Mean $\mathrm{d} b / \mathrm{d} z_{\mathrm{abl}}\left(0.47 \pm 0.12 \mathrm{~m}\right.$ w.e. $(100 \mathrm{~m})^{-1}$; Table 2$)$ is lower than the neighbouring Chhota Shigri Glacier $(0.68 \pm 0.12$ $\mathrm{m}$ w.e. $(100 \mathrm{~m})^{-1}$; Mandal and others, 2020). Glacier vertical massbalance gradients are an essential factor in understanding the climate setting of a glacier (Oerlemans, 2001). $\mathrm{d} b / \mathrm{d} z_{\mathrm{abl}}$ is mainly controlled by the difference in air temperature at different altitudes. Table 3 provides the vertical mass-balance gradient $(\mathrm{d} b / \mathrm{d} z)$ of recently measured glaciers in the Himalayan region. The $\mathrm{d} b / \mathrm{d} z$ values in the Nepalese Himalaya were mostly vertically steep except for Mera Glacier, which has a relatively gentle gradient $(0.46 \mathrm{~m}$ w.e. $(100 \mathrm{~m})^{-1} \mathrm{a}^{-1}$ ) compared to other Himalayan glaciers (Table 3 ). One of the possible reasons for such low $\mathrm{d} b / \mathrm{d} z$ at Mera Glacier was due to continuous snowfall/accumulation on the glacier surface during summer, which subdues the ablation (Sherpa and others, 2017). However, for Patsio Glacier, $\mathrm{d} b / \mathrm{d} z$ was calculated only for the ablation zone, which shows a gentle gradient $(0.47$ $\mathrm{m}$ w.e. $\left.(100 \mathrm{~m})^{-1} \mathrm{a}^{-1}\right)$ as compared to Chhota Shigri and Stok glaciers. A low $\mathrm{d} b / \mathrm{d} z$ observed at Patsio Glacier could be due to significant ablation observed even at the higher altitudes (Fig. 2). Such high ablation is possibly due to the fine dust/sediments (Fig. S5a) present on the glacier surface between 5200 and $5350 \mathrm{~m}$ a.s.l. which tends to modify the albedo leading to enhanced ablation.

During $B_{\mathrm{w}}$ measurements, at the lower altitude (4900-5100 m a.s.l.) snow distribution showed less variability with altitude (Fig. 5). The summer season starts at the end of May in the Lahaul-Spiti region (Singh and others, 2019). Glaciers in the Lahaul-Spiti region fall within the range of 4000-6000 $\mathrm{m}$ a.s.l. (Vijay and Braun, 2016). Patsio Glacier is situated at higher altitudes, where the glacier snout is located at $4875 \mathrm{~m}$ a.s.l. Such higher regions remain cold during the early summer period (Mandal and others, 2020). Therefore, there is less possibility of snow ablation at Patsio Glacier surface during the early summer season. Correction analysis of $B_{\mathrm{w}}$ due to variation in dates are beyond the scope for this study however, the mean vertical gradient observed during the study period falls within the error range. Our $B_{\mathrm{w}}$ measurements show a low vertical mass-balance gradient (mean of $0.29 \pm 0.12$ $\mathrm{m}$ w.e. $\left.(100 \mathrm{~m})^{-1}\right)$. The possible reason for shallow $\mathrm{d} b / \mathrm{d} z B_{\mathrm{w}}$ is due to continuous snowfall and cold temperature during the winter season, which has been observed in this region (Dimri and Dash, 2012; Negi and others, 2017).

$B_{\mathrm{a}}$ and $B_{\mathrm{w}}$ show a systematic interannual variability (Fig. 6). A significant positive correlation $(r=0.82, p<0.05)$ between $B_{\mathrm{a}}$ and $B_{\mathrm{w}}$ for the period 2012-17 was observed. Similarly, a correlation coefficient of $r=0.76$ was observed between $B_{\mathrm{a}}$ and $B_{\mathrm{w}}$ of Chhota Shigri Glacier between 2009 and 2019. A positive correlation $(r=0.98)$ was found for Stok Glacier, however, the $B_{\mathrm{a}}$ and $B_{\mathrm{w}}$ were based on modelling (Soheb and others, 2020). The probable reasons for a good correlation between $B_{\mathrm{a}}$ and $B_{\mathrm{w}}$ are due to 
Table 3. Comparison of glaciological mass balance $\left(B_{\mathrm{a}}\right)$ and vertical mass-balance gradients $(\mathrm{d} b / \mathrm{d} z)$ of measured glaciers in the Himalayan region for the period 2010-17

\begin{tabular}{|c|c|c|c|c|c|c|c|c|}
\hline $\begin{array}{l}\text { Glacier, region } \\
\text { (country) }\end{array}$ & $\begin{array}{c}\mathrm{d} b / \mathrm{d} z(\mathrm{SD}) \\
\mathrm{m} \text { w.e. }(100 \mathrm{~m})^{-1} \\
\mathrm{a}^{-1}\end{array}$ & $\begin{array}{c}\text { Glacier } \\
\text { altitude } \\
\text { range } \\
\text { m a.s.l. }\end{array}$ & $\begin{array}{c}\text { Glacier area } \\
\text { (debris) } \\
\mathrm{km}^{2}\end{array}$ & $\begin{array}{c}\text { Cumulative } B_{\mathrm{a}} \\
\text { (mean) } \\
\text { m w.e. }\end{array}$ & Period & Region & $\begin{array}{l}\text { Major } \\
\text { precipitation } \\
\text { source }\end{array}$ & Source \\
\hline $\begin{array}{l}\text { Patsio, Lahaul-Spiti } \\
\text { (India) }\end{array}$ & $\begin{array}{l}{ }^{\star} 0.47(0.12) \\
5100-5350\end{array}$ & $4875-5718$ & $2.25(12 \%)$ & $-2.35(0.34)$ & $2010-17$ & $\begin{array}{l}\text { Western } \\
\text { Himalaya }\end{array}$ & Westerlies & This study \\
\hline $\begin{array}{l}\text { Chhota Shigri, } \\
\text { Lahaul-Spiti (India) }\end{array}$ & $\begin{array}{c}0.75(0.06) \\
{ }^{*} 0.634464-4798\end{array}$ & $4072-5830$ & $15.5(4 \%)$ & $-2.53(0.36)$ & $2010-17$ & $\begin{array}{l}\text { Western } \\
\text { Himalaya }\end{array}$ & Westerlies & Mandal and others (2020) \\
\hline Stok, Ladakh (India) & $0.61(0.14)$ & $5300-5850$ & $0.74(0)$ & $-1.31(0.44)$ & 2014-17 & $\begin{array}{l}\text { Western } \\
\text { Himalaya }\end{array}$ & Westerlies & Soheb and others (2020) \\
\hline $\begin{array}{l}\text { Mera, Everest region } \\
\text { (Nepal) }\end{array}$ & $0.46(0.09)$ & $4910-6390$ & $5.1(3 \%)$ & $-1.49(0.21)$ & $2010-17$ & $\begin{array}{l}\text { Eastern } \\
\text { Himalaya }\end{array}$ & $\begin{array}{l}\text { Indian summer } \\
\text { monsoon }\end{array}$ & Wagnon and others (2021) \\
\hline $\begin{array}{l}\text { Pokalde, Khumbu } \\
\text { valley (Nepal) }\end{array}$ & $1.16(0.33)$ & $5430-5690$ & $0.1(0)$ & $-4.49(0.64)$ & $2010-17$ & $\begin{array}{l}\text { Eastern } \\
\text { Himalaya }\end{array}$ & $\begin{array}{l}\text { Indian summer } \\
\text { monsoon }\end{array}$ & Wagnon and others (2021) \\
\hline $\begin{array}{l}\text { West Changri Nup, } \\
\text { Khumbu valley (Nepal) }\end{array}$ & $1.49(0.31)$ & $5330-5690$ & $0.9(0)$ & $-9.52(1.36)$ & $2010-17$ & $\begin{array}{l}\text { Eastern } \\
\text { Himalaya }\end{array}$ & $\begin{array}{l}\text { Indian summer } \\
\text { monsoon }\end{array}$ & Wagnon and others (2021) \\
\hline $\begin{array}{l}\text { Rikha Samba } \\
\text { Dhaulagiri (Nepal) }\end{array}$ & $1.48(0.25)$ & $5416-6515$ & $5.7(0)$ & $-2.34(0.39)$ & 2011-17 & $\begin{array}{l}\text { Eastern } \\
\text { Himalaya }\end{array}$ & $\begin{array}{l}\text { Indian summer } \\
\text { monsoon }\end{array}$ & Stumm and others (2020) \\
\hline Yala, Langtang (Nepal) & $1.04(0.12)$ & $5168-5661$ & $1.61(0)$ & $-4.45(0.74)$ & 2011-17 & $\begin{array}{l}\text { Eastern } \\
\text { Himalaya }\end{array}$ & $\begin{array}{l}\text { Indian summer } \\
\text { monsoon }\end{array}$ & Stumm and others (2020) \\
\hline
\end{tabular}

${ }^{*} \mathrm{db} / \mathrm{dz}$ of the ablation zone.

snow accumulation over the glacier surface, which protects the glacier ice from melting during summer, due to the albedo effect (Mölg and others, 2008; Azam and others, 2014; Zhu and others, 2015). Also, the less snow cover led to early exposure of glacier surface, ultimately increases the glacier ablation duration.

\subsection{Mass balance and meteorological parameters}

Precipitation contribution in the Lahaul-Spiti region was $\sim 75 \%$ in winter and $\sim 25 \%$ in summer seasons (area-averaged precipitation for Lahaul-Spiti district; see Section 3.2). Similarly, the contribution of winter and summer precipitation measured at the Chhota Shigri Glacier base camp (2012-17) was $~ 71$ and $29 \%$, respectively (Azam and others, 2019). To make a consistent comparison, we divided the total precipitation into annual, winter and summer, corresponding to the measured mass-balance periods (Fig. 3). A comparison between $B_{\mathrm{a}}$ (after removing two positive $B_{\mathrm{a}}$ years) of Patsio Glacier and positive temperature sum $\left(\sum T_{\text {air }+}\right)$ recorded at Chhota Shigri Glacier show a significant negative correlation $(r=0.91, p<0.05)$. In $2011 / 12$ and $2015 / 16, B_{\mathrm{w}}$ measurement shows almost similar values i.e. 0.88 and $0.9 \mathrm{~m}$ w.e., respectively. However, $B_{\mathrm{a}}$ in $2015 / 16$ was more negative $(-0.68 \mathrm{~m}$ w.e.) than that in $2011 / 12$ ( $-0.51 \mathrm{~m}$ w.e.). Higher negative $B_{\mathrm{a}}$ in $2015 / 16$ corresponds well with the higher summer temperature, especially $\sum T_{\text {air+ }}$ (Table S2). Similarly, high ablation observed on Stok Glacier in 2015/16 correlates with high summer temperature, which resulted in an increased negative $B_{\mathrm{a}}$ compared to other years (Soheb and others, 2020). In 2013/14, Patsio Glacier experienced a low ablation and accumulation, which correlates well with the summer temperature and annual precipitation (Fig. 3 and Table S2) during the study period. In the same line, $\sum T_{\text {air }}$ recorded at Chhota Shigri in 2013/14 was lowest for the study period (2010-17). Comparison between seasonal mass balance and meteorological parameters at Chhota Shigri Glacier showed that air temperature was the primary governing factor of $B_{\mathrm{a}}$ (Mandal and others, 2020). Subsequently, summer snowfall also plays a subequal role in governing the $B_{\mathrm{a}}$ of Chhota Shigri Glacier. However, the timing and intensity were crucial (Azam and others, 2014; Mandal and others, 2020). In 2014/15, summer snowfall might have played an essential role in subduing the ablation (albedo feedback) at Patsio Glacier, when $B_{\mathrm{a}}$ was close to zero. We noticed heavy snowfalls during summer field visits in 2015. Also, high

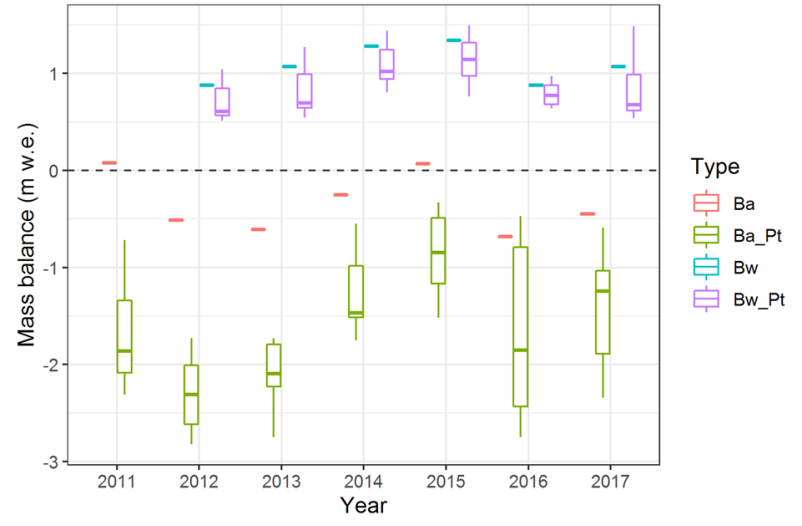

Fig. 6. Box plots of interannual variation of mass-balance measurements of both annual and winter. $B_{\mathrm{a}} \mathrm{Pt}$ represents the annual point mass balance excluding the positive mass-balance measurements (from 2010/11 to 2016/17), and $B_{w_{-}} P t$ is the winter point mass-balance measurements (from 2011/12 to 2016/17). $B_{\mathrm{a}}$ and $B_{\mathrm{w}}$ are the annual and winter mass balance.

precipitation was recorded during summer 2015 (Fig 3 and Table S2). Soheb and others (2020) also found a good correlation between high summer precipitation and low ablation for a couple of years in Stok Glacier. Multiple regression analysis of $B_{\mathrm{a}}$ versus annual and summer precipitation shows a significant positive correlation $(r=0.78)$. A correlation coefficient analysis between seasonal mass balance and precipitation is given in Table S3. Overall, we noticed a similar variation in $B_{\mathrm{a}}$ of Patsio, Chhota Shigri and Stok glaciers during 2010-17 (Table S2). Therefore, winter and summer precipitation (snowfall) including summer temperature plays a significant role in glacier ablation ultimately $B_{\mathrm{a}}$ at Patsio and the neighbouring glaciers. However, for detailed and accurate statistical analysis we need an uninterrupted continuous temperature and precipitation dataset from the different glaciers, which is one of the most challenging but utmost requirements in the Himalayan region for glacier-climate interaction studies.

\subsection{Comparison of mass balance with other studies}

The cumulative $B_{\mathrm{a}}$ of Patsio Glacier between 2010 and 2017 is $-2.35 \mathrm{~m}$ w.e. $\left(-0.34 \mathrm{~m}\right.$ w.e. $\left.\mathrm{a}^{-1}\right)$ which is similar to the cumulative $B_{\mathrm{a}}$ of $-2.53 \mathrm{~m}$ w.e. $\left(-0.36 \mathrm{~m}\right.$ w.e. $\left.\mathrm{a}^{-1}\right)$ for Chhota Shigri Glacier 
for the same period (Mandal and others, 2020). Similarly, interannual variability of $B_{\mathrm{a}}$ for Patsio (SD of $\pm 0.32 \mathrm{~m} \mathrm{w}$.e. $\mathrm{a}^{-1}$ ) and Chhota Shigri glaciers (SD of $\pm 0.34 \mathrm{~m}^{\text {w.e. }} \mathrm{a}^{-1}$ ) was almost similar. $B_{\mathrm{a}}$ variability of Stok Glacier, which is $\sim 130 \mathrm{~km}$ north of Patsio, was $0.26 \mathrm{~m}$ w.e. $\mathrm{a}^{-1}$ for the period 2014-17. Similarly, the cumulative $B_{\mathrm{a}}$ of Stok Glacier between 2014/15 and 2016/17 ( 3 years) was $-1.31 \mathrm{~m}$ w.e. $\left(-0.44 \mathrm{~m}\right.$ w.e. $\mathrm{a}^{-1}$ ) (Soheb and others, 2020). The mean $B_{\mathrm{w}}$ of Patsio Glacier was $1.11 \mathrm{~m}$ w.e. $\mathrm{a}^{-1}$, which coincides with the mean $B_{\mathrm{w}}\left(1.07 \mathrm{~m}\right.$ w.e. $\left.\mathrm{a}^{-1}\right)$ of Chhota Shigri Glacier for the period (2011/12 to 2016/17). Similarly, the cumulative $B_{\mathrm{w}}(6.63 \mathrm{~m}$ w.e.) of Patsio Glacier is concurrent with the cumulative $B_{\mathrm{w}}$ of Chhota Shigri Glacier $(6.42 \mathrm{~m}$ w.e.). Also, the year-to-year variation pattern of $B_{\mathrm{a}}$ and $B_{\mathrm{w}}$ of Patsio Glacier corresponds well to Chhota Shigri and Stok glaciers (Table S2). The above similarities indicate that at present, the above glaciers are responding similarly for the period 2010-17.

Estimation of glacier mass balance in the Lahaul-Spiti region is carried out mostly through remotely sensed geodetic method (Guo and others, 2014; Brun and others, 2017; Shean and others, 2020). Most of the study shows a negative geodetic mass balance in the recent past (Vincent and others, 2013; Vijay and Braun, 2016; Brun and others, 2017; Shean and others, 2020). A negative mass loss of $-0.44 \pm 0.16 \mathrm{~m}$ w.e. $\mathrm{a}^{-1}$ for the periods $1999-2010$ was observed over the Lahaul-Spiti region by Vincent and others (2013) and $-0.45 \pm 0.13 \mathrm{~m}$ w.e. $\mathrm{a}^{-1}$ by Gardelle and others (2013) for the same period. Brun and others (2017) estimated a geodetic mass balance using ASTER data and showed a negative mass loss of $-0.37 \pm 0.09 \mathrm{~m}$ w.e. $\mathrm{a}^{-1}$ for the Lahaul-Spiti region during 2000-16. Recently, Shean and others (2020) estimated a negative geodetic mass balance of $-0.31 \pm 0.08 \mathrm{~m}$ w.e. $\mathrm{a}^{-1}$ for the Lahaul-Spiti region for the period 2000-18 using high-resolution DEMs (WorldView/GeoEye) and ASTER data. They estimated a slightly lower geodetic mass balance of $-0.20 \pm 0.07 \mathrm{~m}$ w.e. $\mathrm{a}^{-1}$ for Patsio Glacier individually. The observed value of Shean and others (2020) is slightly lower than that of Brun and others (2017) but within the error range. Geodetic mass balance estimated on Patsio Glacier using SRTM-X and TanDEM-X for the period 2000-13 shows a mass loss of $-0.26 \pm 0.11 \mathrm{~m}$ w.e. $\mathrm{a}^{-1}$ (Kumar and others, 2018), which is slightly lower than most of the region-wide geodetic estimates. The low negative mass balance observed during 2000-13, could be due to a couple of positive mass-balance years observed in this region, e.g. 2005, 2009-11 (Azam and others, 2012; Negi and others, 2013; Mandal and others, 2020). Overall, the Lahaul-Spiti region has experienced a negative mass loss in the past two decades. The observed mean $B_{\mathrm{a}}\left(-0.34 \mathrm{~m}\right.$ w.e. $\left.\mathrm{a}^{-1}\right)$ of Patsio Glacier is also concordant with the geodetic and glaciological estimates observed for the Lahaul-Spiti glaciers (Mandal and others, 2020), especially with the observation of Brun and others (2017) and Shean and others (2020). Also, in situ measurements at the higher altitudes of Patsio Glacier show ablation, which further confirms the geodetic observations made by Brun and others (2017).

Table 3 presents the glaciological mass balance observed in the Himalayan region for the period 2010-17. The annual mass balance observed in eastern Nepal shows a higher mass loss in comparison with the western Himalayan region except for Mara and Rikha Samba glaciers which show a similar mass loss (Table 3). However, large variability in glacier mass loss has been observed in the eastern Himalayan region, which has been explained mainly by altitudinal differences of the different glaciers (Sherpa and others, 2017). Overall, glaciological mass-balance observations across the Himalaya show negative mass balance in the recent periods.

\section{Conclusion}

We present the annual and winter glacier-wide mass balance of Patsio Glacier, which is the first-ever long-term in situ mass- balance datasets of a glacier from the Bhaga basin in the Lahaul-Spiti region. $B_{\mathrm{a}}$ measurements reveal that Patsio Glacier has lost mass at the rate of $-0.34 \mathrm{~m}$ w.e. $\mathrm{a}^{-1}$ from 2010 to 2017. However, during the winter season, Patsio Glacier has accumulated mass at the rate of $1.11 \mathrm{~m}$ w.e. $\mathrm{a}^{-1}$. The inter-annual variability of $B_{\mathrm{w}}$ was smaller than that of $B_{\mathrm{a}}$. Also, a low spatiotemporal variation was observed for $B_{\mathrm{w}}\left(\mathrm{d} b / \mathrm{d} z B_{\mathrm{w}}\right.$ of $0.21 \mathrm{~m}$ w.e. $\left.(100 \mathrm{~m})^{-1}\right)$ during the study period (2012-17).

Statistical analysis between $B_{\mathrm{w}}$ and $B_{\mathrm{a}}$ shows a positive correlation $(r=0.82, p<0.05)$ indicating the role of winter accumulation in governing the annual mass balance during the study period. The spatial variation of point annual mass balance of Patsio Glacier was primarily governed by the non-climatic factors, especially the debris-cover and glacier orientation/aspect. Based on our observation and other related studies, it is apparent that the glaciers in this region are responding roughly at a similar magnitude during the study period.

Despite having some limitations, this study provides baseline datasets of annual and winter mass balance from one of the most data scare regions of the world. However, the long-term seasonal mass-balance measurements are required to validate the positive correlation between winter and annual mass balance along with the geodetic mass-balance measurements to support the glaciological observations.

Supplementary material. The supplementary material for this article can be found at https://doi.org/10.1017/jog.2021.60.

Acknowledgements. This study was partially supported by Space Application Centre (SAC)-Indian Space Research Organisation (ISRO), Government of India (GOI) and GLACINDIA project, a joint project between the Department of Science and Technology (DST), GOI and Research Council of Norway (RCN). The authors are highly thankful for our ex-glacier group members, Dr Parmanand Sharma, Dr Anurag Linda and Dr Jose George Pottakkal for helping in initiating and conducting mass-balance measurements at the beginning of the study period. We are highly grateful to the Scientific Editor Argha Banerjee and the two anonymous referees whose detailed comments and suggestions have significantly improved the paper. TA is grateful to Jawaharlal Nehru University, for the laboratory facilities throughout the study period. The authors are grateful for various glacier training programmes conducted by DST, GOI, and also for CHARIS project. We are also thankful to all the field experts and assistants, especially Mr Adikari, who helped in conducting the fieldwork. Finally, we thank the USGS for Landsat and SRTM data, Planet Labs for PlanetScope image and Indian Meteorological Department for precipitation data.

Author contributions. TA, AM, MS, VBS, SV and SM conducted the field measurements. TA performed all calculations, analysed all data and wrote the paper. ALR supervised, conceptualised and modified the manuscript in all stages. IMB made comments on the draft, final proofreading with suggestions and arranged partial funding. AM helped in writing the manuscript and produced the final figures. MS helped in improving the manuscript and figures. SV and SM helped in improving the manuscript.

\section{References}

Acharya A and Kayastha R (2018) Mass and energy balance estimation of Yala glacier (2011-2017), Langtang Valley, Nepal. Water 11(1), 6. doi: 10. 3390/w11010006

Armstrong RL and 12 others (2018) Runoff from glacier ice and seasonal snow in high Asia: separating melt water sources in river flow. Regional Environmental Change 19, 1249-1261. doi: 10.1007/s10113-018-1429-0.

Azam MF and 10 others (2012) From balance to imbalance: a shift in the dynamic behaviour of Chhota Shigri glacier, western Himalaya, India. Journal of Glaciology 58(208), 315-324. doi: 10.3189/2012JoG11J123

Azam MF and 6 others (2014) Processes governing the mass balance of Chhota Shigri Glacier (western Himalaya, India) assessed by point-scale surface energy balance measurements. The Cryosphere 8(6), 2195-2217. doi: https://doi.org/10.5194/tc-8-2195-2014

Azam MF and 10 others (2016) Meteorological conditions, seasonal and annual mass balances of Chhota Shigri Glacier, western Himalaya, India. Annals of Glaciology 57(71), 328-338. doi: 10.3189/2016AoG71A570 
Azam MF and 5 others (2018) Review of the status and mass changes of Himalayan-Karakoram glaciers. Journal of Glaciology 64(243), 61-74. doi: 10.1017/jog.2017.86

Azam MF and 7 others (2019) Snow and ice melt contributions in a highly glacierized catchment of Chhota Shigri Glacier (India) over the last five decades. Journal of Hydrology 574, 760-773. doi: 10.1016/j.jhydrol.2019. 04.075

Banerjee A and Shankar R (2013) On the response of Himalayan glaciers to climate change. Journal of Glaciology 59(215), 480-490. doi: 10.3189/ 2013JoG12J130

Bhambri R and 5 others (2013) Heterogeneity in glacier response in the upper Shyok valley, northeast Karakoram. The Cryosphere 7(5), 1385-1398. doi: 10.5194/tc-7-1385-2013

Bolch T and 11 others (2019) Status and change of the cryosphere in the extended Hindu Kush Himalaya region. In Wester P, Mishra A, Mukherji $\mathrm{A}$ and Shrestha $\mathrm{AB}$ (eds), The Hindu Kush Himalaya Assessment: Mountains, Climate Change, Sustainability and People. Cham: Springer International Publishing, pp. 209-255. doi: 10.1007/978-3-319-92288-1_7

Bolch T, Pieczonka T, Mukherjee K and Shea J (2017) Brief communication: Glaciers in the Hunza catchment (Karakoram) have been nearly in balance since the 1970s. The Cryosphere 11(1), 531-539. doi: 10.5194/ tc-11-531-2017

Bookhagen B, Thiede RC and Strecker MR (2005) Abnormal monsoon years and their control on erosion and sediment flux in the high, arid northwest Himalaya. Earth and Planetary Science Letters 231(1), 131-146. doi: 10 1016/j.epsl.2004.11.014

Brun F and 6 others (2019) Heterogeneous influence of glacier morphology on the mass balance variability in high Mountain Asia. Journal of Geophysical Research 124, 1331-1345. doi: 10.1029/2018JF004838

Brun F, Berthier E, Wagnon P, Kääb A and Treichler D (2017) A spatially resolved estimate of high mountain Asia glacier mass balances from 2000 to 2016. Nature Geoscience 10(9), 668-673. doi: 10.1038/ngeo2999

Cogley JG and 9 others (2011) Glossary of glacier mass balance and related terms. IHP-VII Technical Documents in Hydrology No. 86, IACS Contribution No. 2, UNESCO-IHP, Paris

Cuffey K and Paterson WSB (2010) The Physics of Glaciers, 4th Edn. Burlington, MA: Butterworth-Heinemann/Elsevier.

Dimri AP and Dash SK (2012) Wintertime climatic trends in the western Himalayas. Climatic Change 111(3-4), 775-800. doi: 10.1007/s10584011-0201-y

Dobhal DP, Mehta M and Srivastava D (2013) Influence of debris cover on terminus retreat and mass changes of Chorabari Glacier, Garhwal region, central Himalaya, India. Journal of Glaciology 59(217), 961-971. doi: 10. 3189/2013JoG12J180

Dyurgerov MB and Meier MF (1997) Year-to-year fluctuations of global mass balance of small glaciers and their contribution to sea-level changes. Arctic and Alpine Research 29(4), 392. doi: 10.2307/1551987

Dyurgerov MB and Meier MF (1999) Analysis of winter and summer glacier mass balances. Geografiska Annaler: Series A, Physical Geography 81(4), 541-554.

Farinotti D, Immerzeel WW, de Kok RJ, Quincey DJ and Dehecq A (2020) Manifestations and mechanisms of the Karakoram glacier anomaly. Nature Geoscience 13(1), 8-16. doi: 10.1038/s41561-019-0513-5

Gardelle J, Berthier E, Arnaud Y and Kääb A (2013) Region-wide glacier mass balances over the Pamir-Karakoram-Himalaya during 1999-2011. The Cryosphere 7(4), 1263-1286. doi: https://doi.org/10.5194/tc-7-12632013

Gardner AS and 15 others (2013) A reconciled estimate of glacier contributions to sea level rise: 2003 to 2009. Science 340(6134), 852-857. doi: 10 . $1126 /$ science. 1234532

Guo $\mathbf{Z}$ and 6 others (2014) Temporal and spatial changes in Western Himalayan firn line altitudes from 1998 to 2009. Global and Planetary Change 118, 97-105. doi: 10.1016/j.gloplacha.2014.03.012

Huss $\mathbf{M}$ and Fischer M (2016) Sensitivity of very small glaciers in the Swiss Alps to future climate change. Frontiers in Earth Science 4, 34. doi: 10. 3389/feart.2016.00034.

Immerzeel WW, van Beek LPH and Bierkens MFP (2010) Climate change will affect the Asian water towers. Science 328(5984), 1382-1385. doi: 10. 1126/science. 1183188

Kaser G, Fountain A and Jansson P (2003) A manual for monitoring the mass balance of mountain glaciers. Paris, UNESCO. International Hydrological Programme (IHP-VI. Technical Documents in Hydrology 59).
Kenzhebaev R and 5 others (2017) Mass balance observations and reconstruction for Batysh Sook Glacier, Tien Shan, from 2004 to 2016. Cold Regions Science and Technology 135, 76-89. doi: 10.1016/j.coldregions. 2016.12.007

Kumar A and 6 others (2018) Estimation of recent changes in thickness and mass balance of the Patsio glacier in the Great Himalayan region using geodetic technique and ancillary data. Geocarto International 35(1), 4763. doi: 10.1080/10106049.2018.1506506.

Laha S and 7 others (2017) Evaluating the contribution of avalanching to the mass balance of Himalayan glaciers. Annals of Glaciology 58(75pt2), 110-118. doi: 10.1017/aog.2017.27.

Mandal A and 9 others (2020) Understanding the interrelationships among mass balance, meteorology, discharge and surface velocity on Chhota Shigri Glacier over 2002-2019 using in situ measurements. Journal of Glaciology 66(256), 727-741. https://doi.org/10.1017/jog.2020.42.

Maurer JM, Schaefer JM, Rupper S and Corley A (2019) Acceleration of ice loss across the Himalayas over the past 40 years. Science Advances 5(6), eaav7266. doi: 10.1126/sciadv.aav7266.

Mölg T, Cullen NJ, Hardy DR, Kaser G and Klok L (2008) Mass balance of a slope glacier on Kilimanjaro and its sensitivity to climate. International Journal of Climatology 28(7), 881-892. doi: 10.1002/joc.1589

Negi HS and 5 others (2017) Observed spatio-temporal changes of winter snow albedo over the north-west Himalaya: winter snow albedo over the north-west Himalaya. International Journal of Climatology 37(5), 23042317. doi: $10.1002 /$ joc. 4846

Negi HS, Saravana G and Rout R (2013) Monitoring of great Himalayan glaciers in Patsio region, India using remote sensing and climatic observations. Current Science 105(10), 10.

Oerlemans J (2001) Glaciers and Climate Change. Rotterdam: A. A. Balkema Publishers.

Pratap B and 6 others (2019) Reconciling high glacier surface melting in summer with air temperature in the semi-arid zone of western Himalaya. Water 11(8), 1561. doi: 10.3390/w11081561

Pratap B, Dobhal DP, Bhambri R, Mehta M and Tewari VC (2016) Four decades of glacier mass balance observations in the Indian Himalaya. Regional Environmental Change 16(3), 643-658. doi: 10.1007/s10113015-0791-4

Pritchard HD (2019) Asia's shrinking glaciers protect large populations from drought stress. Nature 569(7758), 649-654. doi: 10.1038/s41586-0191240-1

Raina V, Kaul M and Singh S (1977) Mass-balance studies of Gara Glacier. Journal of Glaciology 18(80), 415-423. doi: 10.3189/S0022143000021092

Sakai A and Fujita K (2017) Contrasting glacier responses to recent climate change in high-mountain Asia. Scientific Reports 7(1), 13717. doi: 10. 1038/s41598-017-14256-5

Schmidt S and Nüsser M (2017) Changes of high altitude glaciers in the trans-Himalaya of Ladakh over the Past Five Decades (1969-2016). Geosciences 7(2), 27. doi: 10.3390/geosciences7020027

Shean DE and 5 others (2020) A systematic, regional assessment of high Mountain Asia glacier mass balance. Frontiers in Earth Science 7, 363. doi: $10.3389 /$ feart.2019.00363

Sherpa SF and 8 others (2017) Contrasted surface mass balances of debris-free glaciers observed between the southern and the inner parts of the Everest region (2007-15). Journal of Glaciology 63(240), 637-651. doi: 10.1017/ jog.2017.30

Singh KK and 6 others (2018) Temporal change and flow velocity estimation of Patseo Glacier, Western Himalaya, India. Current Science 114(04), 776. doi: $10.18520 / \mathrm{cs} / \mathrm{v} 114 / \mathrm{i04} / 776-784$

Singh AT and 7 others (2019) Moisture sources for precipitation and hydrograph components of the Sutri Dhaka Glacier Basin, Western Himalayas. Water 11(11), 2242. doi: 10.3390/w11112242

Soheb $\mathbf{M}$ and 5 others (2020) Mass balance observation, reconstruction and sensitivity of Stok glacier, Ladakh region, India, between 1978 and 2019. Journal of Glaciology 66(258), 627-642. https://doi.org/10.1017/jog.2020.34.

Sold L and 8 others (2016) Mass balance re-analysis of Findelengletscher, Switzerland; benefits of extensive snow accumulation measurements. Frontiers in Earth Science 4, 18. doi: 10.3389/feart.2016.00018.

Stumm D, Joshi SP, Gurung TR and Silwal G (2020) Mass balances of Yala and Rikha Samba Glacier, Nepal from 2000 to 2017. Earth System Science Data Discussion [preprint]. doi:10.5194/essd-2020-272 (in review).

Sunako S, Fujita K, Sakai A and Kayastha RB (2019) Mass balance of Trambau Glacier, Rolwaling region, Nepal Himalaya: in-situ observations, 
long-term reconstruction and mass-balance sensitivity. Journal of Glaciology 65(252), 605-616 doi: 10.1017/jog.2019.37.

Thibert E, Blanc R, Vincent C and Eckert N (2008) Glaciological and volumetric mass-balance measurements: error analysis over 51 years for Glacier de Sarennes, French Alps. Journal of Glaciology 54(186), 522-532. doi: 10. 3189/002214308785837093

Thibert E, Eckert N and Vincent C (2013) Climatic drivers of seasonal glacier mass balances: an analysis of 6 decades at Glacier de Sarennes (French Alps). The Cryosphere 7(1), 47-66. doi: 10.5194/tc-7-47-2013

Vijay S and Braun M (2016) Elevation change rates of glaciers in the Lahaul-Spiti (Western Himalaya, India) during 2000-2012 and 20122013. Remote Sensing 8(12), 1038. doi: 10.3390/rs8121038

Vincent C and 10 others (2013) Balanced conditions or slight mass gain of glaciers in the Lahaul and Spiti region (northern India, Himalaya) during the nineties preceded recent mass loss. The Cryosphere 7(2), 569-582. doi: $10.5194 /$ tc-7-569-2013

Wagnon P and 10 others (2007) Four years of mass balance on Chhota Shigri Glacier, Himachal Pradesh, India, a new benchmark glacier in the western
Himalaya. Journal of Glaciology 53(183), 603-611. doi: 10.3189/ 002214307784409306

Wagnon P and 11 others (2013) Seasonal and annual mass balances of Mera and Pokalde glaciers (Nepal Himalaya) since 2007. The Cryosphere 7(6), 1769-1786. doi: https://doi.org/10.5194/tc-7-1769-2013

Wagnon P and 10 others (2021) Reanalysing the 2007-19 glaciological massbalance series of Mera Glacier, Nepal, Central Himalaya, using geodetic mass balance. Journal of Glaciology 67(261), 117-125. doi: 10.1017/jog. 2020.88

Wang R, Liu S, Shangguan D, Radić V and Zhang Y (2019) Spatial heterogeneity in glacier mass-balance sensitivity across high Mountain Asia. Water 11(4), 776. doi: 10.3390/w11040776

Zemp $\mathbf{M}$ and 14 others (2019) Global glacier mass changes and their contributions to sea-level rise from 1961 to 2016. Nature 568, 382-386. doi: 10 . 1038/s41586-019-1071-0.

Zhu $\mathbf{M}$ and 5 others (2015) Energy- and mass-balance comparison between Zhadang and Parlung No. 4 glaciers on the Tibetan Plateau. Journal of Glaciology 61(227), 595-607. doi: 10.3189/2015JoG14J206 